\title{
Apoptosis-linked changes in the phosphorylation status and subcellular localization of the spliceosomal autoantigen U1-70K
}

\author{
J Dieker ${ }^{1}$, B Cisterna ${ }^{2}$, F Monneaux ${ }^{1}$, M Decossas ${ }^{1}$, J van der Vlag $^{3}$, M Biggiogera ${ }^{2}$ and S Muller ${ }^{*, 1}$
}

Apoptosis consists of highly regulated pathways involving post-translational modifications and cleavage of proteins leading to sequential inactivation of the main cellular processes. Here, we focused on the apoptotic processing of one of the essential components of the mRNA splicing machinery, the U1-70K snRNP protein. We found that at an early stage of apoptosis, before the cleavage of the C-terminal part of the protein by caspase-3, the basal phosphorylation of the Ser140 residue located within the RNA recognition motif, increases very significantly. A caspase-dependent, PP1-mediated dephosphorylation of other serine residues takes place in a subset of U1-70K proteins. The U1-70K protein phosphorylated at Ser140 is clustered in heterogeneous ectopic RNP-derived structures, which are finally extruded in apoptotic bodies. The elaborate processing of the spliceosomal U1-70K protein we identified might play an important role in the regulated breakdown of the mRNA splicing machinery during early apoptosis. In addition, these specific changes in the phosphorylation/dephosphorylation balance and the subcellular localization of the U1-70K protein might explain why the region encompassing the Ser140 residue becomes a central autoantigen during the autoimmune disease systemic lupus erythematosus.

Cell Death and Differentiation (2008) 15, 793-804; doi:10.1038/sj.cdd.4402312; published online 18 January 2008

In higher eukaryotes, the process of gene expression includes transcription, pre-mRNA splicing/processing and translation in the cytoplasm. The macromolecular machinery involved in pre-mRNA splicing, the spliceosome, consists of five small nuclear ribonucleoparticles (snRNPs) called U1, U2 and U4-6 snRNP, and a large number of additional splicing factors. ${ }^{1}$ Splicing factors are supposedly recruited from storage sites, that is interchromatin granules, in the interchromatin space to transcription sites at the periphery of condensed chromatin. The assembly of the spliceosome is initiated by recognition of the $5^{\prime}$ splice site of pre-mRNA by U1 snRNP and mediated by serine/arginine-rich (SR) proteins. ${ }^{2}$ Phosphorylation and dephosphorylation both have an important role in the recruitment of splicing factors and the subsequent regulation of spliceosome assembly and splicing catalysis. ${ }^{3}$ The U1-snRNP-specific U1-70K protein is a highly phosphorylated protein, which contains two SR domains. Phosphorylation of both the SR protein ASF/SF2 and the first SR domain of the $\mathrm{U} 1-70 \mathrm{~K}$ protein are involved in vitro in their interaction. ${ }^{4,5}$ In addition, thiophosphorylation of the U1-70K protein, making it resistant to dephosphorylation by phosphatases, results in complete inhibition of splicing, but not of spliceosome formation. ${ }^{6}$ At least 11-13 natural variants of the U1-70K protein, partially due to phosphorylation, have been found by $2 \mathrm{D}$ analysis. ${ }^{7,8}$ However, very little is known about specific phosphorylated residues in this protein or specific enzymes involved in the functional regulation of the $\mathrm{U} 1-70 \mathrm{~K}$ protein by phosphorylation/dephosphorylation.

Apoptosis is a fast and orderly process consisting of a sequence of steps, depending on the inducer, in which caspases play a central role. Especially caspase-3 cleaves many proteins involved in important cellular processes, such as transcription, mRNA splicing/processing and translation. ${ }^{9}$ In addition, many kinases and phosphatases are targeted for cleavage, which can lead either to their inactivation or activation. ${ }^{10}$ Although several spliceosomal proteins, such as the U1-70K protein, ${ }^{11}$ are targets for caspase-3, it is unclear how the breakdown of the splicing machinery is established. Some nuclear proteins as well as their derived peptides can be followed as they are delocalized during apoptosis $^{12}$ and at a higher structural level, components of interchromatin granules, perichromatin fibrils and the nucleolus, normally present in the interchromatin space, become clustered in so-called heterogeneous ectopic RNP-derived structures (HERDS). ${ }^{13}$

Translocation of post-translationally modified autoantigens in apoptotic bodies and the impaired processing of the latter by macrophages or dendritic cells have been considered as the possible trigger for the autoimmune response in systemic lupus erythematosus (SLE). ${ }^{14,15}$ The U1-70K protein, in particular the RNA recognition motif (RRM), has been identified as an important target for both autoantibodies and

\footnotetext{
${ }^{1}$ Centre National de la Recherche Scientifique (CNRS), Institut de Biologie Moléculaire et Cellulaire, Strasbourg, France; ${ }^{2}$ Laboratorio di Biologia Cellulare e Neurobiologia, Dipartimento di Biologia Animale, Università di Pavia, Italy and ${ }^{3}$ Nephrology Research Laboratory, Nijmegen Centre for Molecular Life Sciences, Radboud University Medical Centre, Nijmegen, The Netherlands

*Corresponding author: S Muller, Institut de Biologie Moléculaire et Cellulaire, CNRS UPR9021, 15 Rue René Descartes, Strasbourg 67084, France.

Tel: + 333884170 22; Fax: + 333886106 80; E-mail: S.Muller@ibmc.u-strasbg.fr

Keywords: spliceosome; apoptosis; U1-70K; phosphorylation; autoimmunity

Abbreviations: CPT, camptothecin; CsA, cyclosporine A; HERDS, heterogeneous ectopic RNP-derived structures; OA, okadaic acid; RRM, RNA recognition motif; SLE, systemic lupus erythematosus; SR, serine/arginine-rich; TMC, tautomycetin

Received 31.7.07; revised 14.12.07; accepted 17.12.07; Edited by B Zhivotovsky; published online 18.1.08
} 
$\mathrm{CD}^{+}{ }^{+}$autoreactive $\mathrm{T}$ cells from mice and patients with lupus. ${ }^{16,17}$ We previously found that a peptide encompassing residues 131-151 in the RRM of the U1-70K protein and phosphorylated at Ser140 (peptide P140) was recognized by $\mathrm{CD}^{+}{ }^{+} \mathrm{T}$ cells from mice and patients with lupus and protected young lupus mice against the disease in contrast to the nonphosphorylated peptide, which was not tolerogenic. ${ }^{18,19}$ In addition, for unknown reasons, the apoptotic form of the protein is a preferred target of autoantibodies. ${ }^{20,21}$ Consequently, we tried to clarify the pathway leading to an immunogenic protein by evaluating the changes in the phosphorylation status of the U1-70K protein during apoptotic conditions with a particular focus on Ser140. We also examined at high resolution the location of the spliceosomal U1-70K protein in apoptotic cells.

\section{Results}

Phosphorylation of Ser140 of the U1-70K protein is increased early during apoptosis. To study potential Ser140 phosphorylation of the U1-70K protein, we generated antibodies to peptide $131-151$ of the U1-70K protein phosphorylated at Ser140 (further designated as anti-PhS140) and to peptide 131-151 containing a nonphosphorylated Ser140 residue (further designated as anti-S140). Western blotting analysis revealed that antiPhS140 recognized several bands between 65 and $75 \mathrm{kDa}$ (Figure 1a, lane 1; Supplementary Figure 1a, lane 1; indicated as variants $1-4)$, whereas anti-S140 recognized predominantly variant 2 in nontreated Jurkat cells (Figure 1a, lane 4; Supplementary Figure 1a, lane 4). Treatment of Jurkat cell extracts with increasing concentrations of alkaline phosphatase (AP) revealed the gradual decrease in the intensity of anti-PhS140 labeling of bands in the $65-75 \mathrm{kDa}$ region, whereas simultaneously an increased intensity of bands in the $65-75 \mathrm{kDa}$ region recognized by anti-S140 was observed (Figure 1a). Pre-immune sera showed no staining of either nontreated or AP-treated cell extracts (Figure 1b). Comparable results were obtained using extracts from HeLa cells (data not shown). Therefore, the U1-70K protein recognized by anti-PhS140, is phosphorylated at Ser140, whereas anti-S140 predominantly recognizes the nonphosphorylated U1-70K protein. Next, we studied the phosphorylation level of Ser140 of the U1-70K protein in Jurkat cells after induction of apoptosis by camptothecin (CPT). We observed an increase in the phosphorylation of Ser140 very early after the induction of apoptosis (Figure 1c and d). The increase of anti-PhS140 staining was observed differently for each $\mathrm{U} 1-70 \mathrm{~K}$ variant, that is, within $1 \mathrm{~h}$ (variant 1 ), after $2 \mathrm{~h}$ (variant 3 ) or after $6 \mathrm{~h}$ (variant 4 ). Variant 2 , only recognized by anti-S140, showed no significant changes after induction of apoptosis. The increase in phosphorylation of Ser140 was detectable before the cleavage of the U1-70K protein, as can be seen by the appearance of a $40 \mathrm{kDa}$ cleavage fragment after approximately $3 \mathrm{~h}$ (Figure 1c, arrow). Interestingly, the $40 \mathrm{kDa}$ cleavage fragment of the U1-70K protein was only recognized by anti-PhS140 and not by anti-S140, suggesting that this fragment is phosphorylated at Ser140. Pre-immune sera did not show recognition of extracts from apoptotic cells (Figure 1b). The increase in phosphorylation of Ser140 also occurred before the cleavage and activation of caspase- 3 and the subsequent cleavage of PARP-1 by caspase-3 (Figure 1c). In addition, Ser140 phosphorylation occurred before the appearance of extensive membrane blebbing (Figure 1e) and the appearance of phosphatidylserine at the cell surface (Figure 1f). Therefore, an increased phosphorylation of several U1-70K protein variants at Ser140 seems to be an early event during apoptosis.

Other residues in the $\mathrm{U} 1-70 \mathrm{~K}$ protein are dephosphorylated during apoptosis. We probed western blots of AP-treated Jurkat (Figure 2) or HeLa cell extracts (data not shown) with an antibody against peptide 183-202 of the U1-70K protein (Figure 2a) and with mAb2.73, which is specific for the U1-70K protein (Figure $2 b$ ). We could distinguish four different protein bands between 65 and $75 \mathrm{kDa}$ corresponding to the U1-70K protein variants recognized by anti-PhS140 (variants 1, 3 and 4) and anti-S140 (variant 2). Dephosphorylation of the cell extract resulted in a progressive disappearance of protein bands in the $65-75 \mathrm{kDa}$ region and the appearance of a new protein band of approximately $60 \mathrm{kDa}$ (indicated as hypoP). Longer AP treatment did not result in a further decrease of the molecular mass of this protein band, therefore, this $\mathrm{U} 1-70 \mathrm{~K}$ variant seems to represent a hypophosphorylated form of the U1-70K protein. Interestingly, during CPT-induced apoptosis, we also observed the appearance of a band at approximately $60 \mathrm{kDa}$ revealed with mAb2.73 (Figure 2c, indicated as variant 5) and anti-peptide 183-202 antibodies (data not shown). In addition, we observed the appearance of variant 5 after induction of apoptosis with anti-FAS antibodies (Figure 2d). For Figure $2 \mathrm{c}$ and $\mathrm{d}$, western blots of two separate experiments were quantified (Figure $2 \mathrm{c} 1$ and $\mathrm{d} 1$ ). The apoptosis-linked appearance of variant 5 correlated most closely with the disappearance of the lowest U1-70K protein band observed in nontreated cells (Figure $2 \mathrm{c}$ and $\mathrm{d}$, variant 4 ), in contrast to AP treatment, which resulted in a gradual decrease of all four U1-70K variants (Figure $2 \mathrm{a}$ and b). A longer exposure of the blot probed with anti-PhS140 shown in Figure $1 \mathrm{~b}$ revealed the presence of variant 5, suggesting that this protein represents an U1-70K variant phosphorylated at Ser140 (Figure 2e). This also revealed a clear increased phosphorylation of Ser140 of U1-70K variant 4 , whereas the amount of this variant decreased as shown with mAb2.73 (Figure 2c). The apoptotic variant 5 had a molecular mass similar to the in vitro dephosphorylated protein when applied to the same SDS-PAGE gel (Figure 2e). The pre-immune serum of the rabbit in which anti-peptide 183-202 antibodies were raised and mouse IgG2a (isotype control for mAb2.73) showed no reactivity with bands in the $60-75 \mathrm{kDa}$ region for extracts of nontreated, CPT-treated cells and AP-treated cell extracts (Supplementary Figure 2a). Together, these results led us to conclude that variant 5 represents a minimal phosphorylated U1-70K protein and that simultaneously to the phosphorylation of Ser140, an extensive dephosphorylation 
a

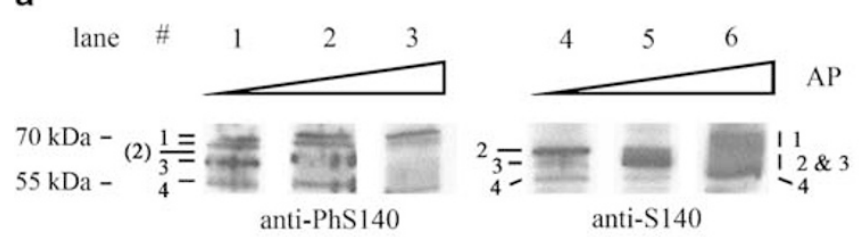

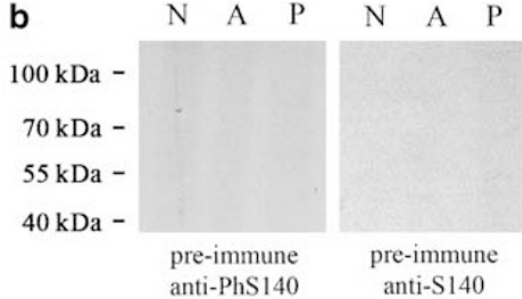

d
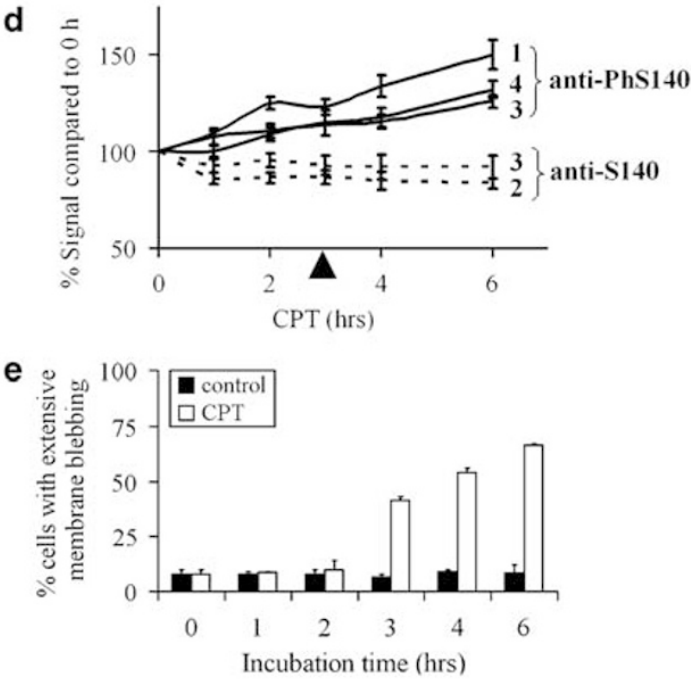

$\mathbf{f}$

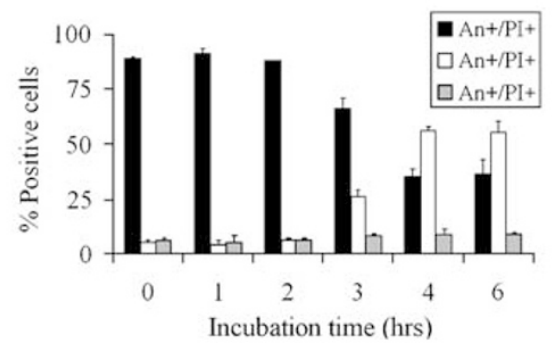

Figure 1 Phosphorylation of Ser140 in the U1-70K protein is increased early during apoptosis. (a) Western blot analysis of extracts from nontreated Jurkat cells dephosphorylated with 0,10 or $25 \mathrm{U}$ of AP. U1-70K variants are numbered 1-4. Note that occasionally a doublet of variant 1 like here can be observed. (b) Pre-immune sera from rabbits collected before immunization with P140 and 131-151 peptides showed no recognition of proteins in extracts from nontreated cells (N), cells treated with CPT for $3 \mathrm{~h}(\mathrm{~A})$ and AP-treated cell extracts (P). (c) The phosphorylation of Ser140 and the cleavage of the U1-70K protein, the cleavage of caspase-3 and the cleavage of PARP-1 during CPT-induced apoptosis in Jurkat cells (times after induction of apoptosis are indicated in the figure). Actin was used as a loading control. Cleavage fragments of the U1-70K protein, caspase-3 and PARP-1 are indicated with arrows. Note that due to the high sensitivity of anti-PhS140 for the $40 \mathrm{kDa}$ fragment, this fragment is already visible in extracts of nontreated cells. (d) Quantification of the data from western blots of three separate experiments by ImageJ software. The signals of the individual U1-70K variants is compared to their signal at $0 \mathrm{~h}$. The arrowhead shows the detection of other apoptosis markers. (e) Percentage of cells with extensive membrane blebbing, scored in 100 cells (in triple) using phase/contrast microscopy. (f) Appearance of phosphatidylserine on the cell surface (Annexin-V; An) and membrane permeabilization (PI) measured in flow cytometry during CPT-induced apoptosis in Jurkat cells. Times after induction of apoptosis are indicated in the figures. U1-70K variants are numbered 1-4, variants not recognized by the respective antibodies are placed in brackets

of other serine residues of the $\mathrm{U} 1-70 \mathrm{~K}$ protein occurs during apoptosis.

Apoptosis-linked dephosphorylation of the U1-70K protein is caspase-dependent. We added the caspase inhibitor DEVD after induction of apoptosis by CPT and tested the effect on the phosphorylation status of the U1-70K protein. Addition of DEVD at a concentration of $20 \mu \mathrm{M}$ could inhibit the appearance of variant 5 and, as expected, the cleavage of the U1-70K protein (Figure $3 a$ and $c$ ). Analysis of the same extracts with an anti-PARP-1 antibody also showed the inhibition of PARP-1 cleavage (Figure 3b). In contrast, we could not detect a significant effect on the apoptosisassociated phosphorylation of Ser140 (data not shown). Although addition of a low concentration $(2 \mu \mathrm{M})$ of DEVD completely inhibited the appearance of variant 5 , we still found cleavage of the U1-70K protein but found no effect on the amount of cells with extensive apoptotic blebbing. This suggests that the apoptosis-associated dephosphorylation is not directly related to cleavage of the U1-70K protein or to the progression of apoptosis.

In addition, we tested the effect of dephosphorylation of the U1-70K protein on its cleavage by recombinant caspase-3 in vitro. We found no difference in the susceptibility to 


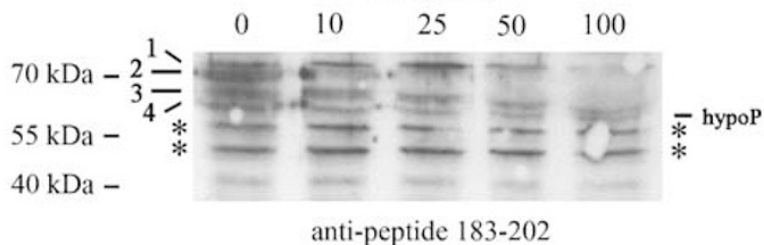

c

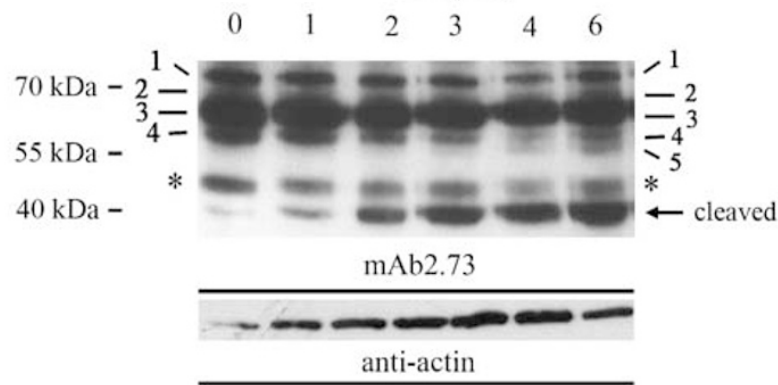

d

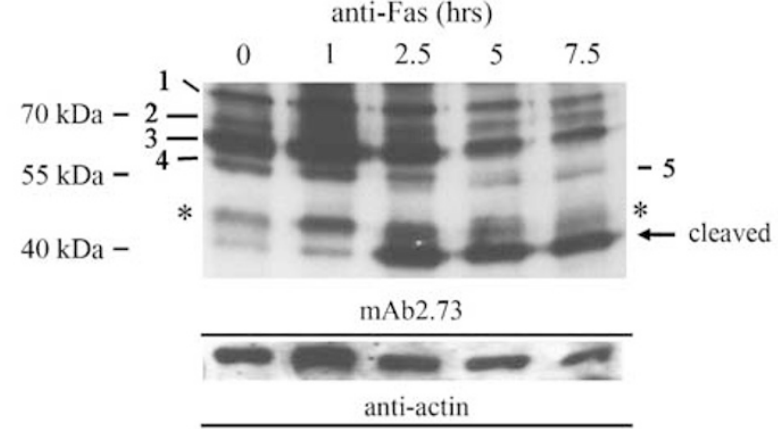

e

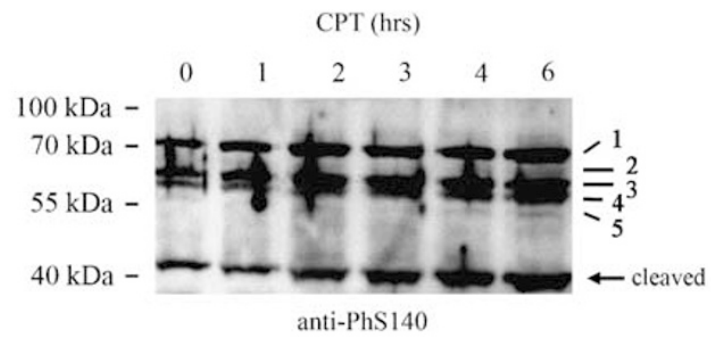

b $\quad \mathrm{AP}$ (units)

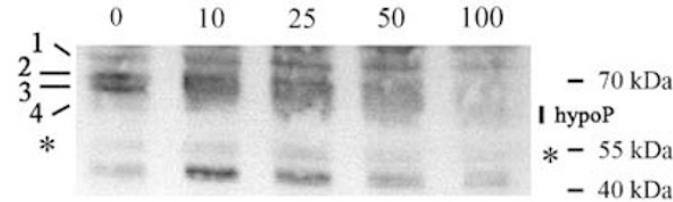

mAb2.73

c1

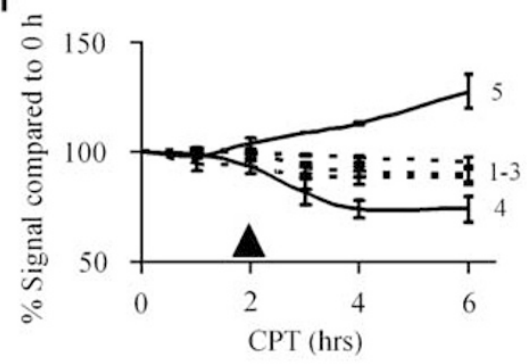

d1

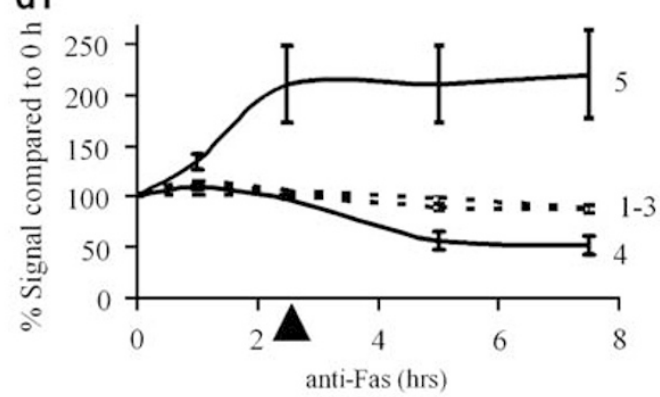

f

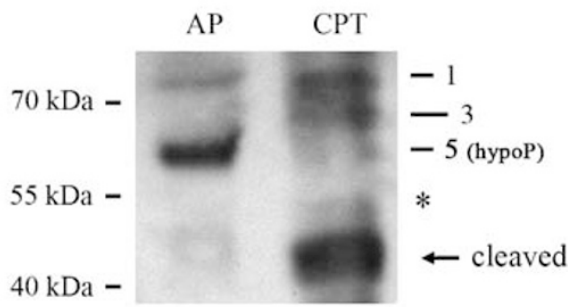

$\mathrm{mAb} 2.73$

Figure 2 Dephosphorylation of the U1-70K protein during apoptosis. (a, b) Western blot analysis of AP-treated extracts from Jurkat cells using anti-peptide 183-202 or mAb2.73 (units of AP added is indicated in the Figure). (c-e) Appearance of a new protein band at approximately $60 \mathrm{kDa}$ (indicated as variant 5) in CPT-treated (c,e) and antiFas antibody-treated Jurkat cells (d) detected with mAb2.73 (c, d) or anti-PhS140 (e). Actin was used as a loading control. Note that the latter picture (e) is a longer exposure time of the blot shown in Figure $1 \mathrm{~b}$. Western blots of two separate experiments shown in panels $\mathrm{c}$ and $\mathrm{d}$ were quantified by ImageJ software (c1, d1). The signals of the individual U1-70K variants are compared to their signal at $0 \mathrm{~h}$. The arrowhead shows the first appearance of cleavage of the U1-70K protein. (f) Comparison of the molecular mass of the U1-70K variants in AP- (lane 1) and CPT-treated extracts (16 h, lane 2). Note that a higher amount of AP-treated extract as compared with that of panel $b$ was applied to make the hypophosphorylated protein clearly visible. In all figures the U1-70K variants are numbered $1-5$ and the $40 \mathrm{kDa}$ fragment is indicated with an arrow. Asterisks represent aspecific bands

cleavage by recombinant caspase-3 between the U1-70K protein present in a nontreated extract (Figure 3d, lane 2) and in an AP-treated cell extract (lane 4).

PP1 is involved in the apoptosis-linked dephosphorylation of the U1-70K protein. As serine/threonine protein phosphatases PP1 and PP2A have been implicated in the regulation of apoptosis ${ }^{22}$ and the regulation of spliceosome assembly and the splicing reaction, ${ }^{23,24}$ we evaluated the possible involvement of these phosphatases in the apoptosis-associated dephosphorylation of the U1-70K protein. Addition of the PP1-specific inhibitor tautomycetin (TMC) resulted in a dose-dependent inhibition of dephosphorylation of the U1-70K protein in CPT-treated cells 
a

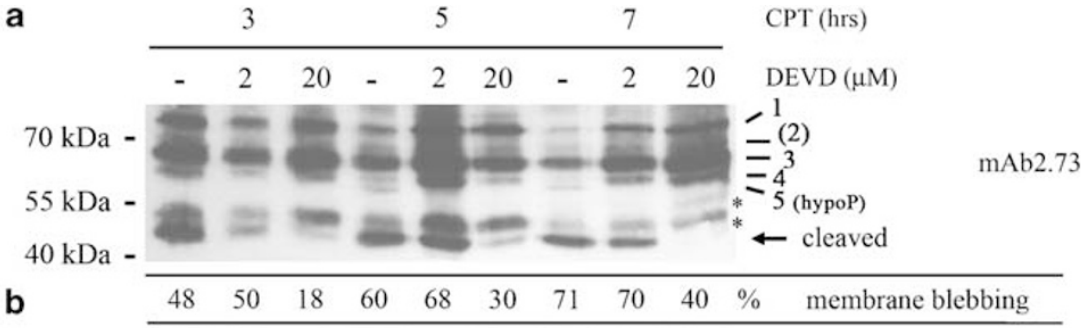

$100 \mathrm{kDa}-$
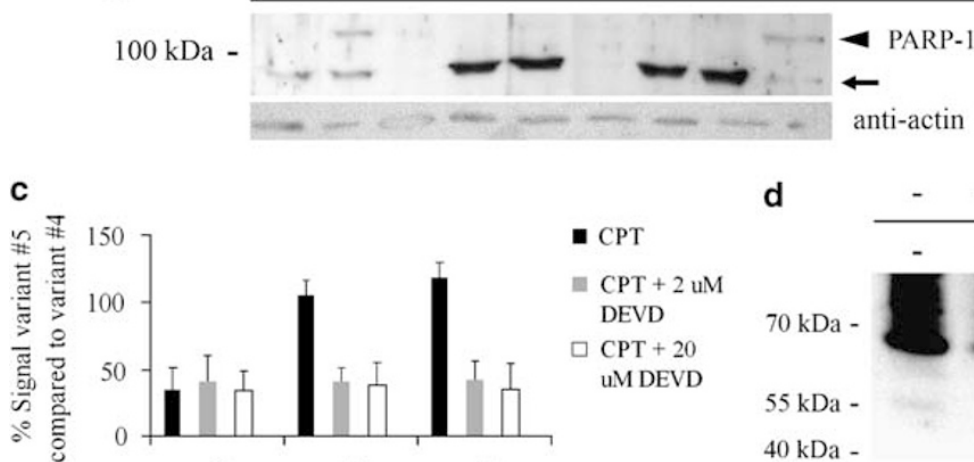

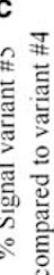

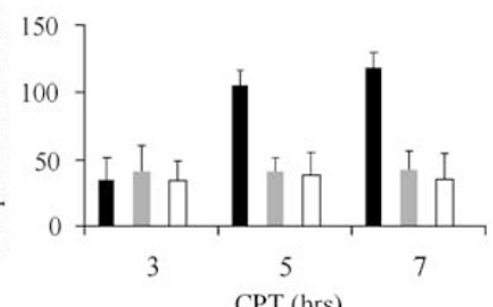

- CPT

In $\mathrm{CPT}+2 \mathrm{uM}$ DEVD

$\square \mathrm{CPT}+20$ UM DEVD

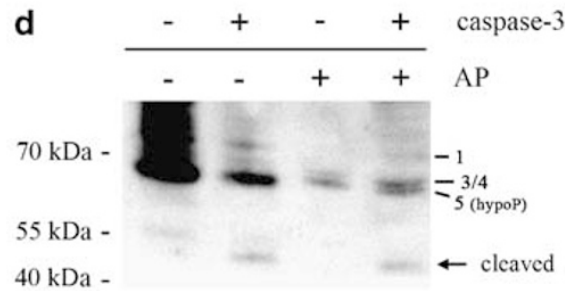

$\mathrm{mAb} 2.73$

Figure 3 Inhibition of caspase-3 prevents the apoptosis-induced appearance of the hypophosphorylated 60-kDa U1-70K protein. (a) Caspase-3 was inhibited during CPTinduced apoptosis in Jurkat cells by addition of 2 or $20 \mu \mathrm{M} \mathrm{DEVD.} \mathrm{The} \mathrm{U1-70K} \mathrm{protein} \mathrm{was} \mathrm{detected} \mathrm{by} \mathrm{mAb2.73.} \mathrm{The} \mathrm{percentage} \mathrm{of} \mathrm{cells} \mathrm{with} \mathrm{extensive} \mathrm{membrane} \mathrm{blebbing} \mathrm{is}$ indicated beneath the figure. Asterisks represent aspecific bands. (b) PARP-1 was used as a control for inhibition of caspase-3 and actin was used as a loading control. (c) Quantification of variants 4 and 5 of the U1-70K protein from three separate experiments after DEVD treatment. The percentage of variant 5 compared with variant 4 is shown. Variants 1-3 showed no significant differences. (d) The cleavage of the U1-70K protein was analyzed by mAb2.73 in Jurkat cell extracts treated with AP and/or recombinant caspase-3. The phosphorylated U1-70K variants and the $40 \mathrm{kDa}$ fragment (arrow) are indicated. Note that the in vitro cleavage of the U1-70K protein by caspase-3 was not complete under these conditions

(Figure $4 \mathrm{a}$ and b). Note in particular that variant 5 disappeared and that variant 4 persisted. In contrast, addition of okadaic acid (OA) at a concentration leading to a specific inhibition of PP2A $(0.1 \mathrm{nM})$ resulted in an enhanced dephosphorylation of the U1-70K protein compared with cells treated with CPT only. Note in particular that compared with nontreated cells shown in the first lane, the intensity of variant 5 increased, whereas the variant 4 completely disappeared. We found no difference when increasing concentrations of OA were used. TMC and OA showed no effect on cleavage of the U1-70K protein (arrow) or on the percentage of cells with extensive membrane blebbing at these concentrations (Figure $4 a$ and $b$ ). We also tested the PP2B inhibitor cyclosporine A (CsA), which resulted in a barely detectable increase of dephosphorylation of the U1$70 \mathrm{~K}$ protein (Figure 4a). However, CsA treatment resulted in an increase in apoptosis observed by an increase in the number of cells with extensive membrane blebbing. Next, we incubated Jurkat cells for different time periods with CPT and with or without $0.1 \mu \mathrm{M}$ of the PP1 inhibitor TMC (Supplementary Figure 3). It appeared that inhibition of PP1 lowered the rate of U1-70K dephosphorylation after induction of apoptosis.

Next, we used mAb2.73 to immunoprecipitate U1-70K protein-containing complexes from extracts of nontreated or CPT-treated Jurkat cells (Figure 4c). We found that PP1 was not co-precipitated by $\mathrm{mAb} 2.73$ in extracts of nontreated cells (lane 2). However, PP1 was co-precipitated at $8 \mathrm{~h}$ after apoptosis induction (lane 4). This kinetics correlated with the appearance of variant 5 . The presence of PP1 in the complex precipitated by mAb2.73 decreased after 16-24 $\mathrm{h}$ of apoptosis (lane 5-6), when we also observed no further increase in the intensity of variant 5 . Conversely, we performed the immunoprecipitation using an anti-PP1 antibody (Figure 4d). Two variants of the U1-70K protein co-precipitated with PP1 in extracts from CPT-treated Jurkat cells (lane 2), but not in extracts from nontreated cells (lane 1). Note that under the applied conditions, PP1 could be precipitated only from extracts of apoptotic cells and not from extracts of nonapoptotic cells. This could be due to an increased expression of PP1 during early apoptosis (data not shown). Finally, we found a dose-dependent decrease in the molecular mass of several U1-70K variants (particularly variant 1) and the appearance of variant 5 in extracts of nontreated cells incubated with increasing concentrations of recombinant PP1 (Figure 4e). Together, we demonstrate the involvement of PP1 in the apoptosis-linked dephosphorylation of the U1-70K protein.

The U1-70K protein phosphorylated at Ser140 is present in perichromatin fibrils and clusters in HERDS during apoptosis. To study the localization of the U1-70K protein phosphorylated at Ser140 in nonapoptotic and apoptotic cells we used mAb2.73 and anti-PhS140 for labeling in immune fluorescence and electron microscopy. In nonapoptotic cells, we found that anti-PhS140 stained particular speckles in the nucleus (Figure 5a). Anti-PhS140-positive speckles were mostly located at the periphery of regions staining with high 

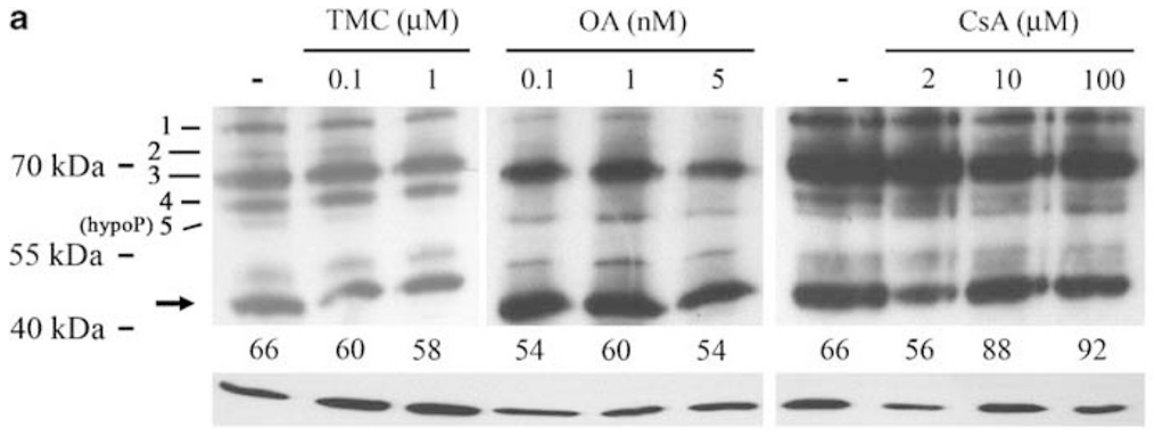

$\begin{array}{lllll}66 & 56 & 88 & 92 \quad \% \text { membrane blebbing }\end{array}$

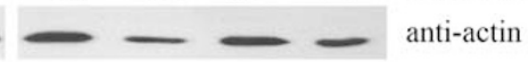

b

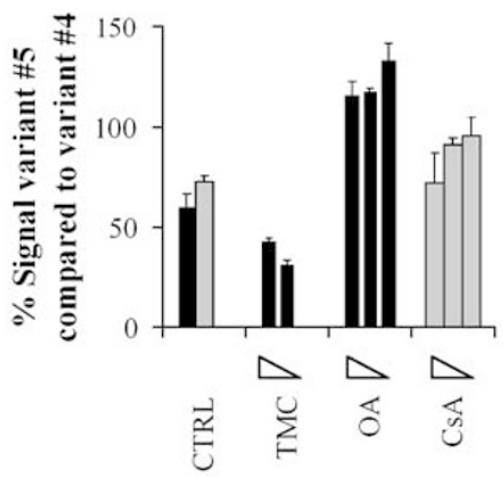

d

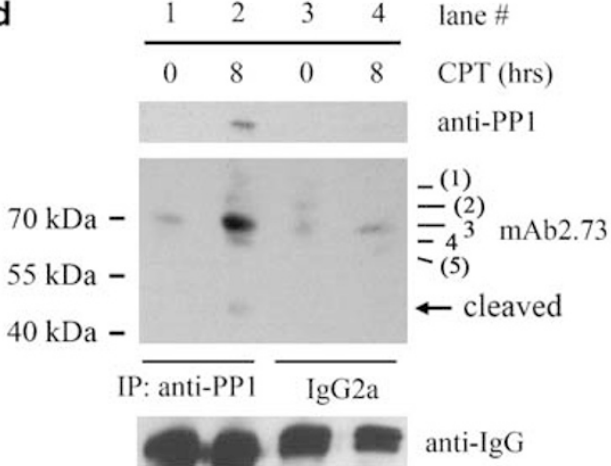

C

\begin{tabular}{rrrrrrl}
1 & 2 & 3 & 4 & 5 & 6 & lane \# \\
\cline { 1 - 4 } 0 & 0 & 4 & 8 & 16 & 24 & CPT (hrs)
\end{tabular}

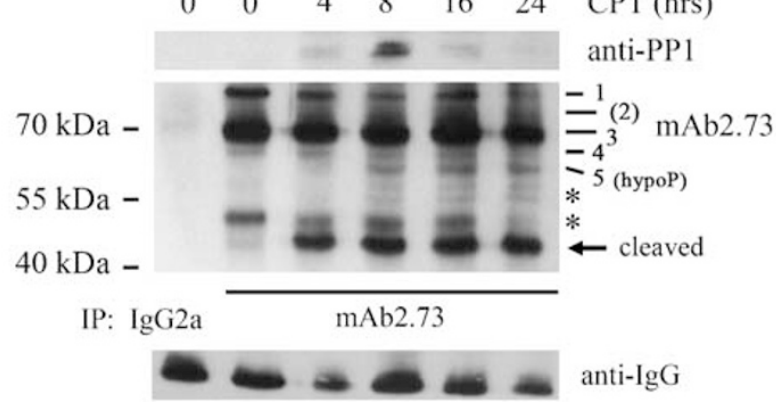

e

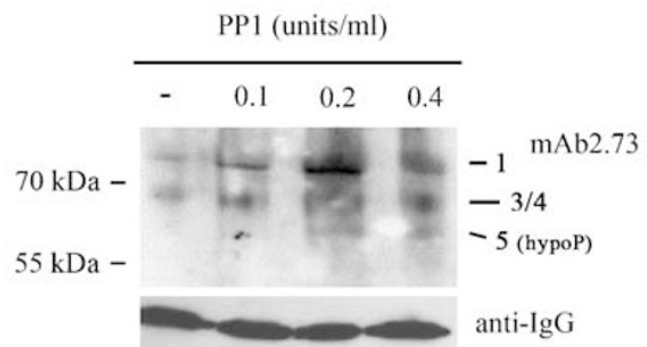

Figure 4 Serine/threonine protein phosphatases are involved in the dephosphorylation of the U1-70K protein during apoptosis. (a) PP1 (0.1 and $1 \mu \mathrm{M}$ TMC), PP2A (0.1, 1 and $5 \mathrm{nM} \mathrm{OA}$ ) and PP2B (2, 10 and $100 \mu \mathrm{M} \mathrm{CsA}$ ) were inhibited during CPT-induced apoptosis ( $7 \mathrm{~h}$ ) in Jurkat cells. Actin was used as a loading control. (b) Quantification of variants 4 and 5 of the U1-70K protein from two separate experiments. The percentage of variant 5 compared with variant 4 is shown. Variants $1-3$ showed no significant differences. (c) mAb2.73 co-precipitates PP1 with the U1-70K protein from extracts of CPT-treated Jurkat cells, which correlates with appearance of the 60-kDa U1-70K protein (variant 5). (d) Anti-PP1 antibody co-precipitates specific variants of the U1-70K protein (variant 3 and 4 ) and weakly the $40 \mathrm{kDa}$ fragment (arrow) in extracts from CPTtreated Jurkat cells. Anti-IgG was used as a loading control in panels $c$ and d. (e) Cell extracts of nontreated Jurkat cells were incubated with the indicated concentrations of recombinant PP1 enzyme. A representative experiment is shown. Note that due to a lower yield after precipitation by mAb2.73 and incubation in PP1-assay buffer, not all variants of the U1-70K protein are visible in the nontreated sample (first lane). Each time the phosphorylated U1-70K variants (1-5) and the 40 kDa fragment (arrow) were detected in western blot with mAb2.73. Variants not recognized by the respective antibodies are placed in brackets

intensity for mAb2.73. In apoptotic cells, we found an evident change in the localization of the U1-70K protein phosphorylated at Ser140, which localized in large clusters also positive for mAb2.73. U1-70K-containing clusters were positive for the proliferation-associated nuclear antigen (PANA), a specific marker for interchromatin granules (Figure $5 b$ and $c$ ).

Interchromatin granules (sites of splicing factors storage) and perichromatin fibrils (sites of transcription and mRNA splicing) can be observed in electron microscopy. ${ }^{25}$ In apoptotic cells, these structures cluster in HERDS. ${ }^{26}$ We observed changes in chromatin structure and the formation of
HERDS (arrowheads) after incubation with CPT for $3 \mathrm{~h}$ (Figure 6a-d). Initially, chromatin had a spongy structure, which still surrounded some HERDS (panel b). Then a complete separation of chromatin and HERDS occurred while the nuclear membrane was still intact (panel c) and finally, the nuclear membrane was degraded and chromatin and HERDS were released into the cytoplasm (panel d). Staining of nontreated cells with mAb2.73 showed localization of the U1$70 \mathrm{~K}$ protein both in interchromatin granules and perichromatin fibrils (Figure 6e). In contrast, anti-PhS140 revealed the presence of the U1-70K protein phosphorylated at Ser140 almost only in perichromatin fibrils (Figure 6f). In apoptotic 
a

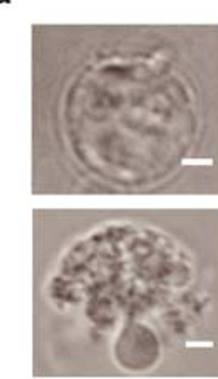

b

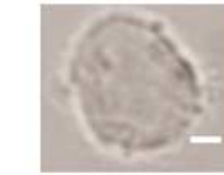

C

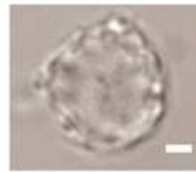

mAb2.73

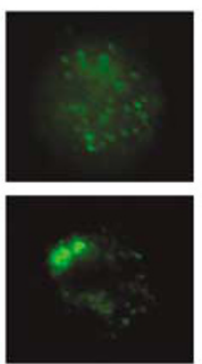

$\mathrm{mAb} 2.73$

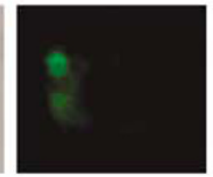

anti-PhS140

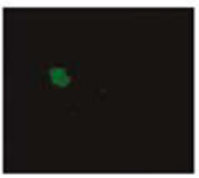

anti-PhS140

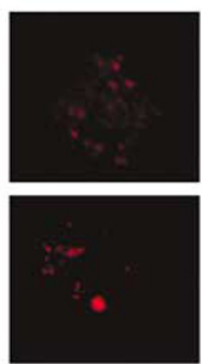

anti-PANA

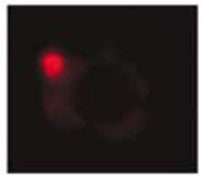

anti-PANA

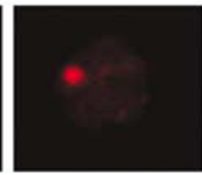

merge
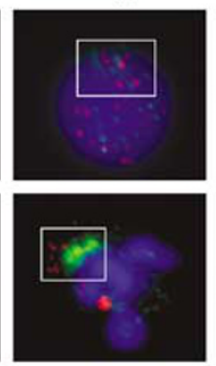

merge

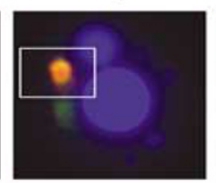

merge

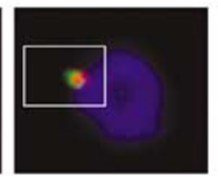

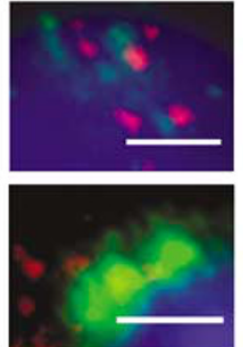

non-apoptotic

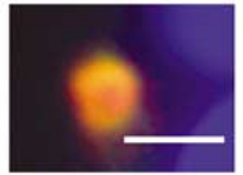

apoptotic

Figure 5 U1-70K phosphorylated at Ser140 is redistributed and clustered in apoptotic cells. The localization of the U1-70K protein in nontreated and CPT-treated Jurkat cells ( $3 \mathrm{~h}$ ) was revealed by double staining with mAb2.73 and anti-PhS140 (a), mAb2.73 and anti-PANA (b) and anti-PhS140 and anti-PANA (c). DNA is stained with DAPI. Phase-contrast light microscopy images are shown on the left. The four pictures on the right correspond to an enlarged view of the indicated box in the respective merged pictures. Scale bar, $2 \mu \mathrm{m}$

cells, labeling with mAb2.73 and anti-PhS140 showed the presence in HERDS of both the U1-70K protein and the $\mathrm{U} 1-70 \mathrm{~K}$ protein phosphorylated at Ser140 (Figure $6 \mathrm{~g}-\mathrm{j}$ ). The labeling with these two antibodies was found almost exclusively at the periphery of the HERDS where interchromatin granules and perichromatin fibrils are still morphologically recognizable.

We found that PP1 was localized in the clusters extruded from chromatin in apoptotic cells using immune fluorescence microscopy. These PP1-positive clusters were often associated with clusters containing the U1-70K protein phosphorylated at Ser140 (Figure 7a and b) and PANA (Figure 7c). In contrast, PP2A was not specifically associated with these clusters (Figure 7d).

The U1-70K protein present in apoptotic bodies is phosphorylated at Ser140. As apoptotic blebs/bodies contain many antigens recognized by lupus autoantibodies, ${ }^{27,28}$ we isolated apoptotic bodies from Jurkat cells after incubation with CPT for $48 \mathrm{~h}$ as described in Materials and Methods. Western blot analysis revealed the presence of the $40 \mathrm{kDa}$ fragment of the $\mathrm{U} 1-70 \mathrm{~K}$ protein in these isolated apoptotic bodies, whereas we could hardly detect any intact phosphorylated or hypophosphorylated U1-70K protein (Figure 8a). We found a very strong recognition of the $40 \mathrm{kDa}$ cleavage fragment by anti-PhS140 compared with antipeptide 183-202. In addition, AP treatment of the extracts from apoptotic bodies resulted in a decreased binding to the $40 \mathrm{kDa}$ cleavage fragment of the U1-70K protein by anti-PhS140 (Supplementary Figure 4). Similar results were found for apoptotic bodies isolated from
anti-FAS-treated cells (data not shown). We also identified PP1 in isolated apoptotic bodies (Figure 8b). Immune fluorescence microscopy revealed that the (apoptotic cleaved) U1-70K protein (Figure 8c-e) was present in apoptotic bodies as clusters. Staining by anti-PhS140 and mAb2.73 showed a partial colocalization in the same clusters. We found that a single apoptotic body contained DNA and the U1-70K protein in separate clusters (Figure $8 \mathrm{c}$ and $\mathrm{e}$ ) or that only one of these nuclear components was present in a single apoptotic body (Figure 8d). Therefore, we conclude that the U1-70K protein present in apoptotic bodies has undergone the apoptosis-associated changes described above, that is, phosphorylation of Ser140, dephosphorylation of additional residues, cleavage by caspase-3 and clustering inside HERDS.

\section{Discussion}

Our results demonstrate that the spliceosomal U1-70K protein undergoes specific changes in its phosphorylation status and subcellular localization early during apoptosis, in addition to the previously described cleavage by caspase-3 (summarized in Supplementary Figure 5). These apoptosis-linked changes target the functional domains of the protein, that is, the RRM, the SR domains and the $\mathrm{C}$ terminus. As the $\mathrm{U} 1-70 \mathrm{~K}$ protein is an essential protein in the U1 snRNP particle, which is involved in the first steps of the splicing reaction ${ }^{1}$ and directly associated with transcription, ${ }^{29}$ these modifications implicate an important role for this protein in a novel pathway involving the breakdown of the mRNA splicing machinery early during apoptosis. In addition, we show that the main target of 

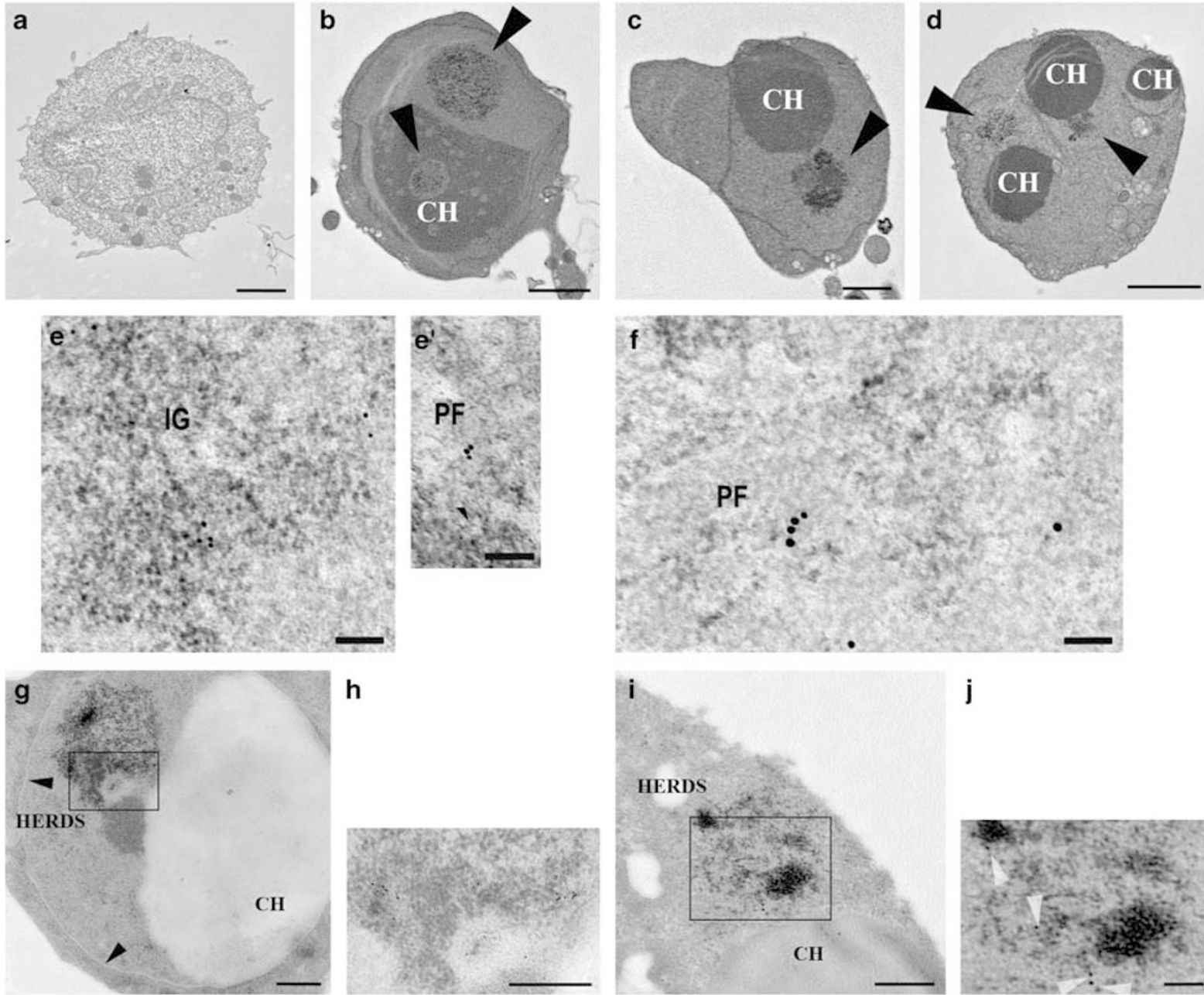

h

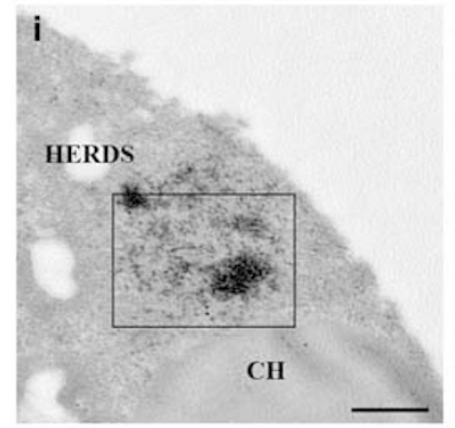

j

$\mathrm{mAb} 2.73$

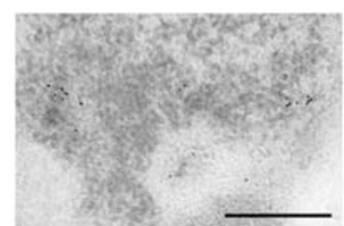

anti-PhS140

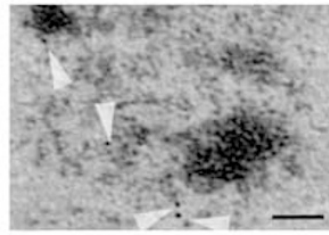

Figure 6 During apoptosis U1-70K phosphorylated at Ser140 is present in HERDS. (a-d) Morphological study of the nuclear changes by electron microscopy of nontreated (a) or CPT-treated Jurkat cells ( $3 \mathrm{~h}, \mathbf{b}-\mathbf{d}$ ) showing the condensation and fragmentation of chromatin and the formation of HERDS (arrowheads). Different stages of the separation of RNP-derived structures from chromatin could be observed; initially chromatin had a spongy structure, which still surrounded some HERDS (b), then a complete separation of chromatin and HERDS occurred while the nuclear membrane was still intact (c) and finally, the nuclear membrane was degraded and chromatin and HERDS were released into the cytoplasm (d). Scale bar, $2 \mu \mathrm{m}$. (e-f) Electron microscopy immunolabeling of the nucleus of Jurkat cells with mAb2.73 (e) or anti-PhS140 (f). The gold particles are present on the interchromatin granules (IG) and perichromatin fibrils (PF) for mAb2.73 and only in perichromatin fibrils for anti-PhS140. Scale bar, $100 \mathrm{~nm} .(\mathbf{g}-\mathbf{j})$ Immunolabeling by mAb2.73 (g, h) and anti-PhS140 (l, j) in electron microscopy shows the localization inside HERDS. Scale bar, $500 \mathrm{~nm}(\mathbf{g}, \mathbf{i})$ or $200 \mathrm{~nm}(\mathbf{h}, \mathbf{j})$. Note that the HERDS visible in panel $g$ are still located in the nucleus (nuclear membrane indicated by arrowheads). Bernhard's EDTA regressive technique was used to bleach the chromatin in panels $\mathrm{e}-\mathrm{j}$

autoantibodies and autoreactive $\mathrm{T}$ cells within the U1-70K protein, that is, the RRM, is modified during apoptosis.

Phosphorylation of Ser140 in the U1-70K RRM. We identified a novel phosphorylation site at Ser140 in the RRM of the U1-70K protein. The U1-70K protein phosphorylated at Ser140 is present on perichromatin fibrils, where transcription and mRNA splicing take place. In contrast, we did not find such phosphorylated U1-70K protein in the interchromatin granules (involved in the storage and assembly of snRNPs). The Ser140 residue is located in the helix $\beta 2-$ helix $\beta 3$ loop that is involved in the binding to U1 RNA according to a model of the homologous RRM in the spliceosomal U1A protein. ${ }^{30}$ Therefore, an intriguing possibility arises that the phosphorylation of
Ser140, by a so far unidentified kinase, plays a role in the regulation of the $\mathrm{U} 1-70 \mathrm{~K}$ protein during mRNA splicing, by affecting its binding to U1 RNA. The increase in phosphorylation of Ser140 we observed early during apoptosis could then be associated with a change in mRNA splicing activity required for the progression of apoptosis. The exact role of Ser140 phosphorylation is currently under investigation.

A novel role for PP1 in the apoptosis-associated dephosphorylation of the U1-70K protein. We show here that at least four different variants of the U1-70K protein can be observed by SDS-PAGE between 65 and $75 \mathrm{kDa}$, which represent different phosphorylation states of the U1-70K protein. During apoptosis, we observed the 


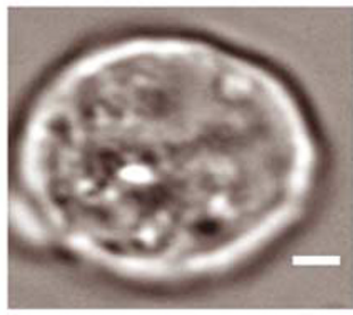

b

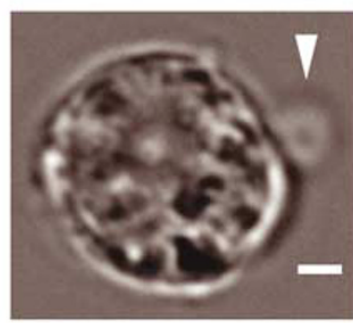

C

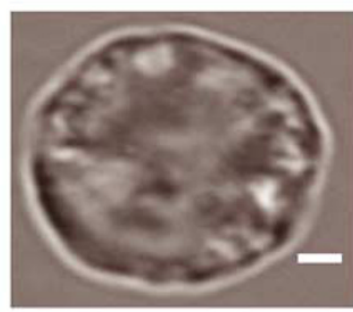

d

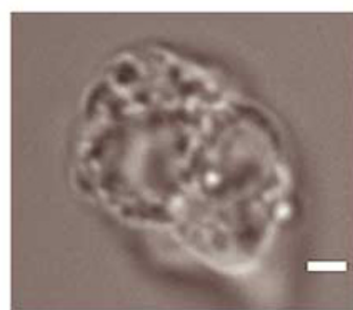

anti-PP1
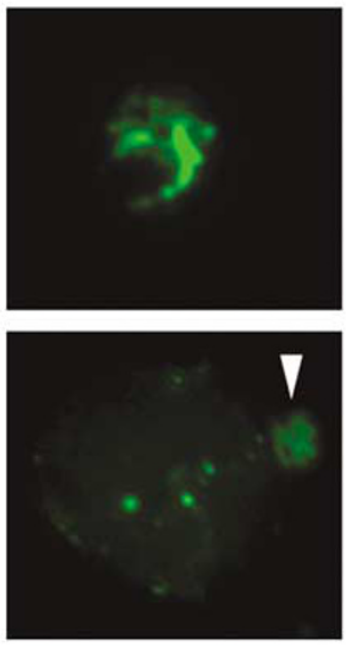

anti-PP1

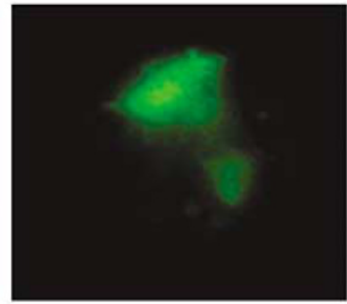

anti-PP2A

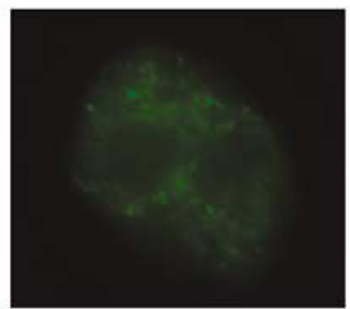

anti-PhS140
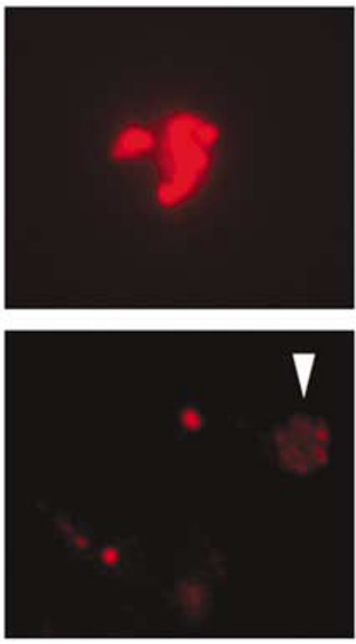

anti-PANA

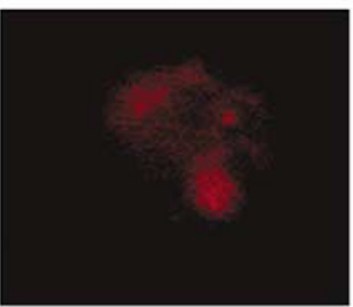

anti-PANA

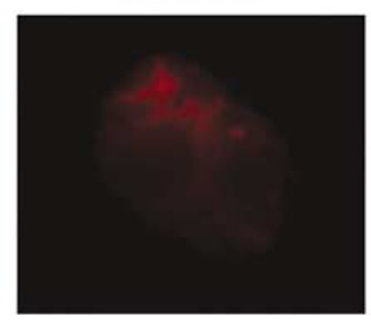

merge
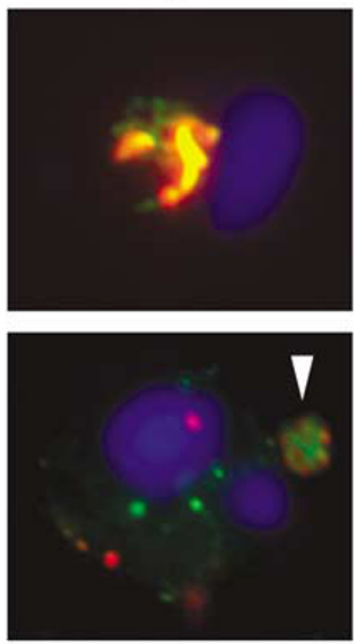

merge

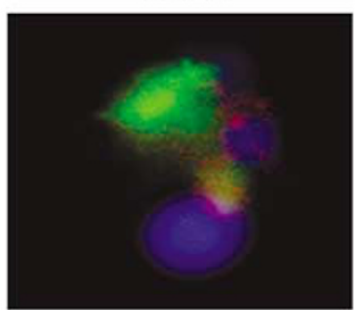

merge

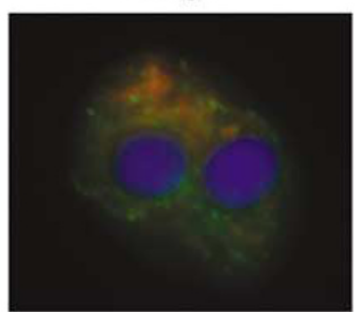

Figure 7 Clustering of PP1 in apoptotic cells. Staining of CPT-treated Jurkat cells $(3 h)$ with anti-PP1 and anti-PhS140 (a, b) or anti-PANA (c). Staining of anti-PP2A and anti-PANA (d) showed no specific clustering of PP2A. DNA is stained with DAPI. An apoptotic bleb is indicated in panel $b$ with an arrowhead. Scale bar, $2 \mu \mathrm{m}$

appearance of a protein band at approximately $60 \mathrm{kDa}$ (variant 5), representing a minimal phosphorylated form of the U1-70K protein. The $40 \mathrm{kDa}$ fragment also seems minimally phosphorylated, as we found no effect of prolonged PP1 or AP treatment on the molecular mass of this fragment. Dephosphorylation of the U1-70K protein seems not necessary for cleavage by caspases; however, caspase activation is absolutely required for the dephosphorylation of the U1-70K protein. In addition, cleavage of SR protein kinases (SRPKs) by caspases leading to inactivation of these enzymes ${ }^{31}$ could result in a decreased phosphorylation rate of the protein. Interestingly, the observed increase of the dephosphorylation by inhibition of PP2A can be explained by an effect on the phosphorylation rate of the $\mathrm{U} 1-70 \mathrm{~K}$ protein, as dephosphorylation of the SR kinase Clk1 by PP2A increases its activity. ${ }^{32}$ The extensive dephosphorylation of the protein during apoptosis will most likely affect the first SR domain, as 10/19 potential serine phosphorylation sites (as predicted by NetPhos 2.0) are located in this domain.

Serine/threonine phosphatases PP1, PP2A and PP2C $\gamma$ are each involved in specific stages of spliceosome assembly and essential for completing the splicing reaction. ${ }^{23,24}$ Our results show a novel role for PP1 in the dephosphorylation of the spliceosomal U1-70K protein during apoptosis. Interestingly, PP1 is also involved in the dephosphorylation of SR proteins during anti-FAS-induced apoptosis. ${ }^{33}$ Therefore, PP1mediated dephosphorylation of the SR domains in both proteins early during apoptosis could result in the loss of the phosphorylation-dependent interaction between these proteins. Consequently, the described SR protein-mediated binding of the U1-70K protein (and the U1 snRNP particle) to RNA polymerase II, the $5^{\prime}$ splicing site and the U2 snRNP particle would be affected. Our data suggest that PP1 is 
a

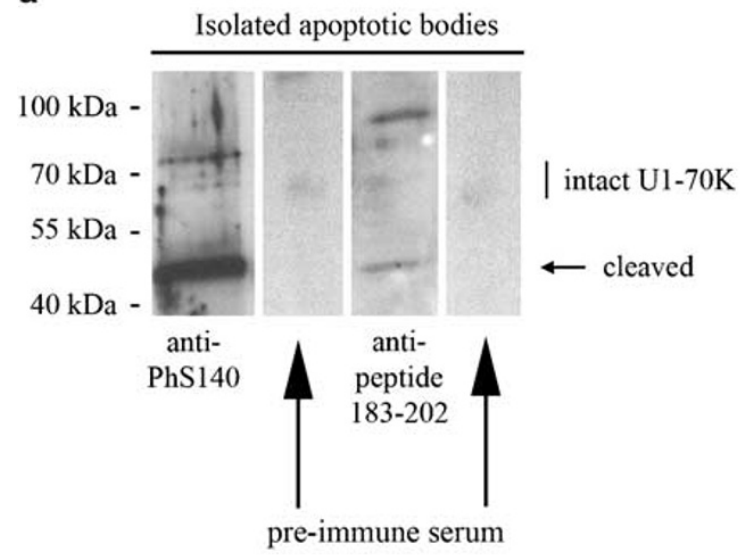

e
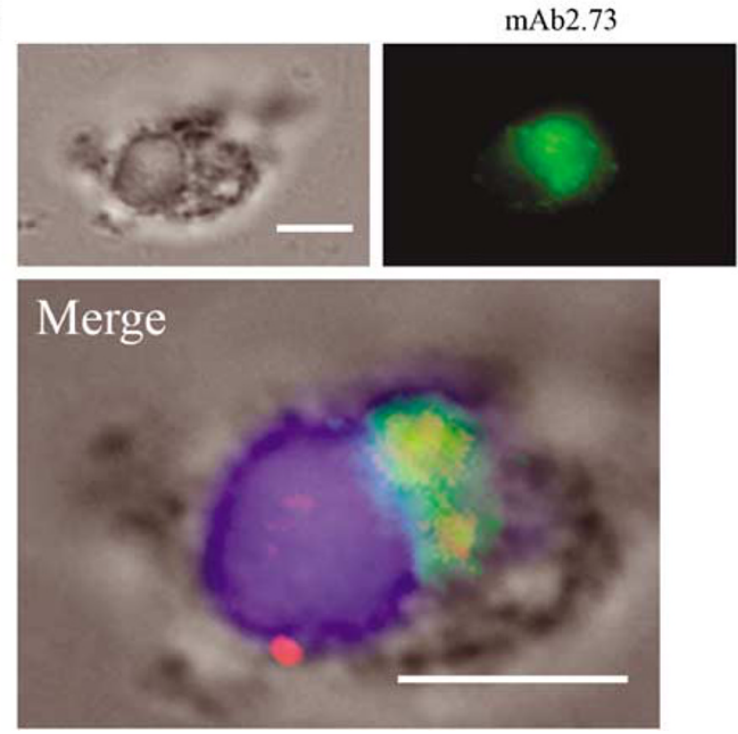

b

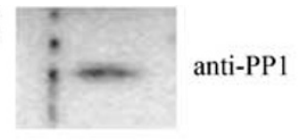

C

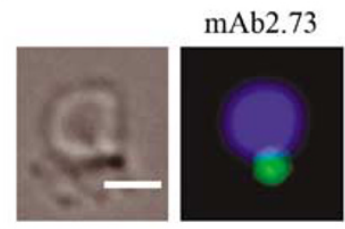

anti-

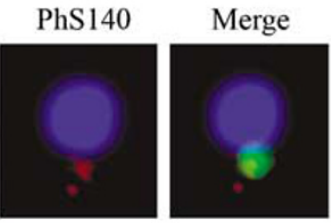

d
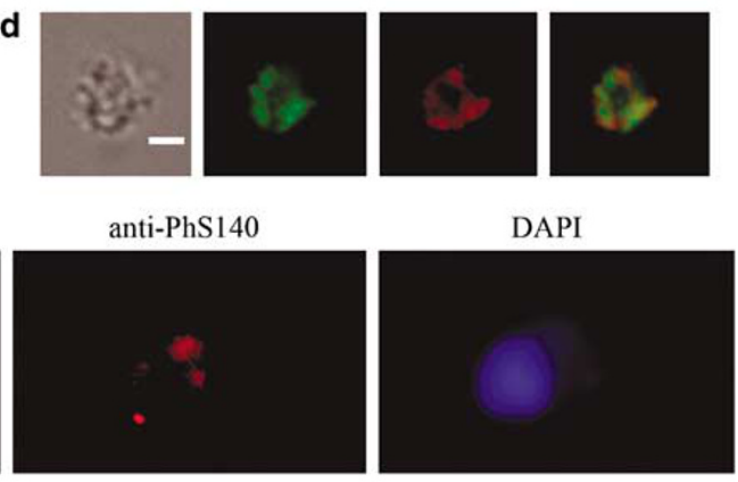

Figure 8 U1-70K present in apoptotic bodies is phosphorylated at Ser140. (a, b) Western blot analysis of isolated apoptotic bodies was performed with anti-PhS140, antipeptide 183-202 and the respective pre-immune sera (a), and anti-PP1 (b). (c-f) Immune fluorescence staining of isolated apoptotic bodies with mAb2.73 and anti-PhS140. DNA is stained by DAPI. Scale bar, $2 \mu \mathrm{m}$

involved in the dephosphorylation of certain phospho-variants of the U1-70K protein during apoptosis. In addition, we found no effect of PP1 inhibition on the molecular mass of the $40 \mathrm{kDa}$ fragment. Therefore, additional phosphatases could be involved, which, as shown, are most likely not PP2A and PP2B.

Interestingly, we found a high expression of PP1 in clusters associated with HERDS. The activation of PP1 and the inactivation of SRPKs (which are associated with the release of SR proteins from interchromatin granules) could play an important role in the clustering of splicing proteins and the formation of HERDS. Indeed, accumulation of splicing factors upon inhibition of transcription (which also induces the formation of HERDS) requires PP1 activity. ${ }^{34}$ Further study has to evaluate the relation between the phosphorylation status of the U1-70K protein, its subcellular localization and the composition of the U1-70K-containing complex. So far, the different kinetics of the apoptosis-linked phosphorylation/ dephosphorylation for each U1-70K variant suggests a different availability for specific kinases and phosphatases.
Role of apoptosis-linked modifications of the U1-70K protein in autoimmunity. Knowledge of the detailed processing of RNA- and DNA-binding proteins during apoptosis is important for the understanding of the autoimmune response in SLE. In this study, we show that the apoptotic $\mathrm{U} 1-70 \mathrm{~K}$ protein is relocated early during apoptosis and clustered inside HERDS, ${ }^{26}$ which are finally released in apoptotic bodies. When considering the high resistance to protease and nuclease digestion shown for interchromatin granules, it is not unlikely that neo-epitopes associated with HERDS, which are structurally based on interchromatin granules, ${ }^{13}$ are protected from degradation. Importantly, the apoptosis-associated change in phosphorylation we identified involves the RRM of the U1-70K protein, which is the main target of SLE autoantibodies and autoreactive $T$ cells. ${ }^{16,17,20,21}$ In addition, we have previously reported the importance of the phosphorylated Ser140 residue in modulating the autoimmune response. ${ }^{18,19}$ Therefore, we propose that the 
apoptotic processing of the $\mathrm{U} 1-70 \mathrm{~K}$ protein results in the formation of neo-epitopes, protected from degradation by the clustering in HERDS, which could induce an autoimmune response when apoptotic cells are not properly cleared.

\section{Materials and Methods}

Antibodies. Antibodies against peptides encompassing residues 131-151, the residues 131-151 with a phosphorylated Ser140 and 183-202 (containing no serine residues) of the U1-70K protein were raised in rabbits. Other antibodies used were mAb2.73 (anti-U1-70K, recognizing RD repeats in the 230-240 region of the U1-70K protein), ${ }^{35}$ anti-PARP, ${ }^{36}$ anti-caspase-3 (BD Biosciences, Erembodegem, Belgium), anti-actin (BD Transduction Laboratories), anti-PANA (Biogenex, San Ramon, USA), anti-PP1 and anti-PP2a-Calpha (both Santa Cruz Biotechnology, Santa Cruz, USA).

Induction of apoptosis and use of caspase and phosphatase inhibitors. Apoptosis was induced by incubating Jurkat or HeLa cells with $2.5 \mu \mathrm{g} / \mathrm{ml}$ of topoisomerase I inhibitor CPT (Sigma, Steinheim, Germany) or $2 \mu \mathrm{g} / \mathrm{ml}$ IgM anti-FAS antibody clone 7C11 (Beckman Coulter, Fullerton, USA) for the indicated times. For inhibition of caspases Z-DEVD-fmk (EMDBiosciences, San Diego, USA) was used. For inhibition of serine/threonine phosphatases PP1, PP2A or PP2B, the indicated concentrations of TMC, OA or CsA (all from EMDBiosciences), respectively, were used. Apoptosis was measured by double staining of Annexin V-allophycocyanin (BD Biosciences) and PI using a FACSCalibur flow cytometer (BD Biosciences).

Immune precipitation, SDS-PAGE and western blotting. Cell extracts were prepared by lysing PBS-washed pelleted cells in lysis buffer (10 mM Tris- $\mathrm{HCl}, \mathrm{pH} 7.4,10 \mathrm{mM} \mathrm{NaCl}, 3 \mathrm{mM} \mathrm{MgCl}, 0.5 \%$ Igepal) supplemented with phosphatase inhibitors $\mathrm{NaF}(1 \mathrm{mM})$ and $\mathrm{NaVa}(1 \mathrm{mM})$ and a cocktail of protease inhibitors (Sigma), and sonicated. Apoptotic bodies were prepared as described previously. ${ }^{37}$ Shortly, apoptosis was induced in Jurkat cells as described above for $48 \mathrm{~h}$ and cell culture supernatant was collected. Two additional centrifugation steps $(800 \times g)$ were performed to remove remaining cells and the supernatant was centrifuged at $17500 \times g$ for $20 \mathrm{~min}$. The pellet containing apoptotic bodies was analyzed in flow cytometry and showed a distinct population positive for Annexin-V and PI. Representative microscopic pictures of isolated apoptotic bodies are shown in Figure 8. Extracts from isolated apoptotic bodies were prepared in the lysis buffer described above. Protein concentration of the prepared extracts was determined by the bi-cinchoninic acid assay (Sigma) with BSA as a standard. For immune precipitation $5 \mu \mathrm{g}$ of antibody was added to $200 \mu \mathrm{g}$ cell extract in a total volume of $150 \mu$ l lysis buffer containing $150 \mathrm{mM} \mathrm{NaCl}$, and incubated overnight at $4^{\circ} \mathrm{C}$. A 30- $\mu$ l volume of Protein A-Sepharose and $170 \mu \mathrm{l}$ of lysis buffer containing $150 \mathrm{mM} \mathrm{NaCl}$ were added and incubated overnight at $4{ }^{\circ} \mathrm{C}$ Sepharose beads were washed five times with lysis buffer containing $150 \mathrm{mM} \mathrm{NaCl}$ and two times with PBS. Precipitated proteins were eluted by adding $50 \mu \mathrm{l}$ sample buffer $(50 \mathrm{mM}$ Tris- $\mathrm{HCl} \mathrm{pH} 7.4,6 \mathrm{M}$ urea, 3\% SDS and $6 \%$ freshly added $\beta$-mercaptoethanol)

Cell extracts $(5-15 \mu \mathrm{g}$ of protein) were resolved by SDS-PAGE and proteins were transferred to nitrocellulose sheets. Blots were blocked with $5 \%$ milk $(\mathrm{w} / \mathrm{v})$ in TBS- $0.05 \%$ Tween 20 (TBS-T). Incubation with the primary antibody was performed for $2 \mathrm{~h}$ in TBS-T, followed by washing and incubation for $2 \mathrm{~h}$ with the corresponding horseradish peroxidase-labeled secondary antibody (Jackson ImmunoResearch, Suffolk, UK). For western blots of immune precipitation experiments, TrueBlot secondary antibodies specific for intact IgG (eBioscience, San Diego, USA) were used. Proteins were visualized using ECL (Amersham Biosciences, Buckinghamshire, UK). Exposed films were quantified by ImageJ software.

Treatment with alkaline phosphatase, recombinant caspase- 3 or PP1. Cell extracts were prepared using the lysis buffer described above, without the addition of phosphatase inhibitors. To $150 \mu \mathrm{g}$ extract, $1 \mathrm{mM} \mathrm{MgCl} 2$ was added together with the indicated units of AP (Zymed, San Francisco, USA) for $2 \mathrm{~h}$ at $37^{\circ} \mathrm{C}$. As a control, another sample of the extract was incubated without AP, but with $1 \mathrm{mM}$ $\mathrm{NaF}$ and $1 \mathrm{mM} \mathrm{Na}_{3} \mathrm{VO}_{4}$. For the treatment with caspase-3, $10 \mu \mathrm{l}$ of AP-treated extract or control extract was incubated with $1000 \mathrm{U}$ recombinant human caspase-3 (EMDBiosciences) in caspase-buffer $(100 \mathrm{mM} \mathrm{NaCl}, 50 \mathrm{mM}$ HEPES, $10 \mathrm{mM}$ DTT, $1 \mathrm{mM}$ EDTA, $10 \%$ glycerol and $0.1 \%$ CHAPS; $\mathrm{pH} 7.0$ ) for $2 \mathrm{~h}$ at $37^{\circ} \mathrm{C}$. PP1 treatment was performed by adding the indicated units of recombinant PP1
(EMDBiosciences) to U1-70K protein precipitated by $\mathrm{mAb2} 2.73$ in a total volume of $20 \mu \mathrm{l}$ of PP1-assay buffer $\left(50 \mathrm{mM}\right.$ Tris-HCl, $5 \mathrm{mM}$ DTT, $200 \mu \mathrm{M} \mathrm{MnCl}_{2}, 100 \mu \mathrm{M}$ EDTA and $200 \mu \mathrm{g} / \mathrm{ml} \mathrm{BSA}, \mathrm{pH} \mathrm{7.0)}$ and incubated overnight at $37^{\circ} \mathrm{C}$.

Immune fluorescence microscopy. Cells were fixed with freshly made $2 \%$ paraformaldehyde in phosphate buffer (PB) for $1 \mathrm{~h}$ at room temperature (RT). The cells were then washed in TBS, incubated with mAb2.73 (1:10), anti-PANA (1:3), anti-PhS140 (1:10), anti-PP1 (1:50) or anti-PP2A (1:10) and subsequently incubated with the corresponding Alexa-conjugated secondary antibodies (Molecular Probes, Eugene, USA). Pictures were obtained with a Zeiss fluorescence microscope (Axiovert $200 \mathrm{M}$ ) using a $\times 63$ magnification. Images were acquired with a digital camera using Axiovision 4.37 software (Zeiss, Le Pecq, France). Images were contrast-enhanced by applying the brightness/contrast regulation of Photoshop 8.0 software to the whole image. Double immunofluorescence images were obtained by superimposing two single-color pictures with Adobe Photoshop.

Electron microscopy. For immunoelectron microscopy, samples of normal and apoptotic Jurkat cells were fixed with 4\% paraformaldehyde in PB for $1 \mathrm{~h}$ at RT and rinsed in TBS. Samples were then imbedded in $2 \%$ low gelling agarose and placed into $0.5 \mathrm{M} \mathrm{NH}_{4} \mathrm{Cl} / \mathrm{PBS}$ for $30 \mathrm{~min}$ at $4{ }^{\circ} \mathrm{C}$, dehydrated in ethanol at RT and embedded in LR White resin. Ultrathin sections were incubated with normal goat serum (NGS) diluted $1: 100$ in TBS for $3 \mathrm{~min}$. mAb2.73 (1:10) and anti-PhS140 (1:10) diluted in TBS containing $0.05 \%$ Tween 20 and $0.1 \%$ BSA, were incubated overnight at $4{ }^{\circ} \mathrm{C}$. After rinsing with TBS-Tween and TBS, samples were incubated with NGS. The appropriate secondary antibody coupled to colloidal gold (Aurion, Wageningen, The Netherlands) was diluted 1:20 in TBS and incubated for $30 \mathrm{~min}$ at RT. As a control, grids were incubated without primary antibody. Finally, samples were rinsed with TBS and distilled water, and stained with Bernhard's EDTA regressive technique, ${ }^{38}$ which preferentially stains RNP-containing nuclear components.

For ultrastructural morphology, samples of normal and apoptotic Jurkat cells were fixed with $2.5 \%$ glutaraldehyde in $\mathrm{PB}$ for $2 \mathrm{~h}$, rinsed in $\mathrm{PB}$ and postfixed in $2 \%$ $\mathrm{OsO}_{4}$ for $30 \mathrm{~min}$. The specimens were imbedded in $2 \%$ low gelling agarose, dehydrated in ethanol at RT and embedded in DURCURPAN resin. Samples were inspected with a Hitachi $\mathrm{H} 600$ electron microscope and images were acquired using a Hamamatsu CCD camera.

Acknowledgements. We thank the RIO Imaging Facility (Plateforme Inter Unités de Microscopie et d'Imagerie Cellulaire Strasbourg Esplanade) for technical assistance and use of their facilities, and Véronique Parietti for purifying large amounts of the mAb2.73 used in this study. This work was supported by grants from the Centre National de la Recherche Scientifique (CNRS), Federations of European Biochemical Societies (FEBS) and the Fondation pour la Recherche Médicale (FRM) to JD and from the University of Pavia to BC.

1. Kramer A. The structure and function of proteins involved in mammalian pre-mRNA splicing. Annu Rev Biochem 1996; 65: 367-409.

2. Will CL, Lührmann R. Spliceosomal UsnRNP biogenesis, structure and function. Curr Opin Cell Biol 2001; 13: 290-301.

3. Misteli T. Cell biology of transcription and pre-mRNA splicing: nuclear architecture meets nuclear function. J Cell Sci 2000; 113: 1841-1849.

4. Cao W, Garcia-Blanco MA. A serine/arginine-rich domain in the human U1-70k protein is necessary and sufficient for ASF/SF2 binding. J Biol Chem 1998; 273: 20629-20635.

5. Xiao SH, Manley JL. Phosphorylation-dephosphorylation differentially affects activities of splicing factor ASF/SF2. EMBO J 1998; 17: 6359-6367.

6. Tazi J, Kornstadt U, Rossi F, Jeanteur P, Cathala G, Brunel C et al. Thiophosphorylation of U1-70K protein inhibits pre-mRNA splicing. Nature 1993; 363: 283-286.

7. Woppmann A, Patschinsky T, Bringmann P, Godt F, Lührmann R. Characterisation of human and murine snRNP proteins by two-dimensional gel electrophoresis and phosphopeptide analysis of U1-specific 70K protein variants. Nucleic Acids Res 1990; 18: $4427-4438$.

8. Woppmann A, Will CL, Kornstadt U, Zuo P, Manley JL, Lührmann R. Identification of an snRNP-associated kinase activity that phosphorylates arginine/serine rich domains typical of splicing factors. Nucleic Acids Res 1993; 21: 2815-2822.

9. Fischer U, Janicke RU, Schulze-Osthoff K. Many cuts to ruin: a comprehensive update of caspase substrates. Cell Death Differ 2003; 10: 76-100.

10. Utz PJ, Anderson P. Life and death decisions: regulation of apoptosis by proteolysis of signaling molecules. Cell Death Differ 2000; 7: 589-602. 
11. Casciola-Rosen LA, Miller DK, Anhalt GJ, Rosen A. Specific cleavage of the 70-kDa protein component of the $\mathrm{U} 1$ small nuclear ribonucleoprotein is a characteristic biochemical feature of apoptotic cell death. J Biol Chem 1994; 269: 30757-30760.

12. Soldani $C$, Bottone MG, Pellicciari C, Scovassi Al. Nucleolus disassembly in mitosis and apoptosis: dynamic redistribution of phosphorylated-c-Myc, fibrillarin and Ki-67. Eur J Histochem 2006; 50: 273-280.

13. Biggiogera $M$, Bottone MG, Scovassi Al, Soldani C, Vecchio L, Pellicciari C. Rearrangement of nuclear ribonucleoprotein (RNP)-containing structures during apoptosis and transcriptional arrest. Biol Cell 2004; 96: 603-615.

14. Dieker JW, van der Vlag J, Berden JH. Deranged removal of apoptotic cells: its role in the genesis of lupus. Nephrol Dial Transplant 2004; 19: 282-285.

15. Sheriff A, Gaipl US, Voll RE, Kalden JR, Herrmann M. Apoptosis and systemic lupus erythematosus. Rheum Dis Clin N Am 2004; 30: 505-527.

16. Monneaux F, Briand JP, Muller S. B and T cell immune response to small nuclear ribonucleoprotein particles in lupus mice: autoreactive CD4(+) T cells recognize a $\mathrm{T}$ cell epitope located within the RNP80 motif of the 70K protein. Eur J Immunol 2000; 30: 2191-2200.

17. Greidinger EL, Foecking MF, Schafermeyer KR, Bailey CW, Primm SL, Lee DR et al. T cell immunity in connective tissue disease patients targets the RNA binding domain of the U1$70 \mathrm{kDa}$ small nuclear ribonucleoprotein. J Immunol 2002; 169: 3429-3437.

18. Monneaux F, Lozano JM, Patarroyo ME, Briand JP, Muller S. T cell recognition and therapeutic effect of a phosphorylated synthetic peptide of the 70K snRNP protein administered in MR/Ipr mice. Eur J Immunol 2003; 33: 287-296.

19. Monneaux F, Hoebeke J, Sordet C, Nonn C, Briand JP, Maillere B et al. Selective modulation of $\mathrm{CD} 4+\mathrm{T}$ cells from lupus patients by a promiscuous, protective peptide analog. J Immunol 2005; 175: 5839-5847.

20. Greidinger EL, Foecking MF, Ranatunga S, Hoffman RW. Apoptotic U1-70 kD is antigenically distinct from the intact form of the U1-70-kd molecule. Arthritis Rheum 2002; 46: $1264-1269$.

21. Hof D, Cheung K, de Rooij DJ, van den Hoogen FH, Pruijn GJ, van Venrooij WJ et al Autoantibodies specific for apoptotic U1-70K are superior serological markers for mixed connective tissue disease. Arthritis Res Ther 2005; 7: R302-R309.

22. Garcia A, Cayla X, Guergnon J, Dessauge F, Hospital V, Rebollo MP et al. Serine/ threonine protein phosphatases PP1 and PP2A are key players in apoptosis. Biochimie 2003; 85: 721-726.

23. Mermoud JE, Cohen P, Lamond Al. Ser/Thr-specific protein phosphatases are required for both catalytic steps of pre-mRNA splicing. Nucleic Acids Res 1992; 20: 5363-5369.

24. Fakan S, Leser G, Martin TE. Ultrastructural distribution of nuclear ribonucleoproteins as visualized by immunocytochemistry on thin sections. J Cell Biol 1984; 98: 358-363.
25. Murray MV, Kobayashi R, Krainer AR. The type $2 \mathrm{C}$ Ser/Thr phosphatase PP2Cgamma is a pre-mRNA splicing factor. Genes Dev 1999; 13: 87-97.

26. Biggiogera M, Bottone MG, Pellicciari $\mathrm{C}$. Nuclear ribonucleoprotein-containing structures undergo severe rearrangement during spontaneous thymocyte apoptosis. A morphological study by electron microscopy. Histochem Cell Biol 1997; 107: 331-336.

27. Casciola-Rosen L, Anhalt G, Rosen A. Autoantigens targeted in systemic lupus erythematosus are clustered in two populations of surface structures on apoptotic keratinocytes. J Exp Med 1994; 179: 1317-1330.

28. Dieker JW, Fransen JH, van Bavel CC, Briand JP, Jacobs CW, Muller S et al. Apoptosisinduced acetylation of histones is pathogenic in systemic lupus erythematosus. Arthritis Rheum 2007; 56: 1921-1933.

29. Das R, Yu J, Zhang Z, Gygi MP, Krainer AR, Gygi SP et al. SR proteins function in coupling RNAP II transcription to pre-mRNA splicing. Mol Cell 2007; 26: 867-881.

30. Katsamba PS, Bayramyan M, Haworth IS, Myszka DG, Laird-Offringa IA. Complex role of the beta 2-beta 3 loop in the interaction of U1A with U1 hairpin II RNA. J Biol Chem 2002; 277: 33267-33274.

31. Utz PJ, Hottelet M, van Venrooij WJ, Anderson P. Association of phosphorylated serine/ arginine (SR) splicing factors with the U1-small ribonucleoprotein (snRNP) autoantigen complex accompanies apoptotic cell death. J Exp Med 1998; 187: 547-560.

32. Menegay HJ, Myers MP, Moeslein FM, Landreth GE. Biochemical characterization and localization of the dual specificity kinase CLK1. J Cell Sci 2000; 113: 3241-3253.

33. Chalfant CE, Ogretmen B, Galadari S, Kroesen BJ, Pettus BJ, Hannun YA. FAS activation induces dephosphorylation of SR proteins; dependence on the de novo generation of ceramide and activation of protein phosphatase 1. J Biol Chem 2001; 276: 44848-44855.

34. Misteli T, Spector DL. Serine/threonine phosphatase 1 modulates the subnuclear distribution of pre-mRNA splicing factors. Mol Biol Cell 1996; 7: 1559-1572.

35. Billings $\mathrm{PB}$, Allen RW, Jensen FC, Hoch $\mathrm{SO}$. Anti-RNP monoclonal antibodies derived from a mouse strain with lupus-like autoimmunity. J Immunol 1982; 128: 1176-1180.

36. Decker P, Briand JP, de Murcia G, Pero RW, Isenberg DA, Muller S. Zinc is an essential cofactor for recognition of the DNA binding domain of poly(ADP-ribose) polymerase by antibodies in autoimmune rheumatic and bowel diseases. Arthritis Rheum 1998; 41 : 918-926.

37. Nauta AJ, Trouw LA, Daha MR, Tijsma O, Nieuwland R, Schwaeble WJ et al. Direct binding of $\mathrm{C}$ 1q to apoptotic cells and cell blebs induces complement activation. Eur J Immunol 2002; 32: 1726-1736.

38. Bernhard W. A new staining procedure for electron microscopical cytology. J Ultrastruct Res 1969; 27: 250-265.

\section{Supplementary Information accompanies the paper on Cell Death and Differentiation website (http://www.nature.com/cdd)}

